\title{
An Empirical Research on Rebooting of Customer Loyalty of Bata Product Through Guerrilla Marketing
}

\author{
Uma Rani Purusothaman, P.Saravanan, A.Mohamed Rafic
}

\begin{abstract}
This study is conducted to examine the rebooting of customer loyalty of Bata products through Guerrilla marketing that helps to sustain their customers. In this era of globalization all firms are facing competition. Bata Company is not an exception. Hence this study will reveal how for this guerilla marketing is effective to sustain in the market. Primary data collected through survey method. Questionnaire constructed and data was collected from customers in Chennai city. Multiple regression analysis tools are used that helps to predict the effect of independent variables on dependent variable. Multiple regression analysis determines the fit of the model and the relative contribution of each of the predictors to the total variance. The variation in loyalty of customers of Bata products through Guerilla marketing is explained by change in design, cost effectiveness, variety of products and offers to attract customers. Each independent variable explains the variance.
\end{abstract}

Keywords: Rebooting customer loyalty, guerrilla marketing, cost effectiveness, dependant variables

\section{INTRODUCTION}

Guerrilla Marketing is a promotional approach that centers on economical marketing campaign that give up maximum return. Bata Company is very concerned about satisfying their local customer needs. They adapt to changes in the design of their shoes according to the taste of their customers. Specialty of Bata is they do not have identical products in all countries. Their shoes are noted for their quality and it is always fashionable. Bata Company was the recipient of Guinness world record for their huge market throughout the world. This success was possible due to their flexible policies. Baby boomers and Gen X favoured Bata for its comfort when wearing their shoes. Bata is facing competition from giant shoe makers like Nike, Reebok, \& Puma. Hence they find difficult to sustain in the market and to achieve their target. To promote their sales, Bata has decided to sell their products through online and gone for social media marketing too. Bata used Guerrilla marketing to reach a large audience. Guerrilla marketing helps big companies to campaign through mass media. Individuals have also adopted this marketing style as a way to find a job or more work.

\section{REVIEW OF LITERATURE}

2.1 Relationship between traditional and guerrilla marketing

As people are very busy, effective marketing becomes essential. The firms must adopt innovative marketing strategy to attract people to buy their products. Guerrilla marketing is definitely a solution to this problem. Organization has to spend huge amount for advertising through Medias like print and television, flyers and bill boards. Development of technology motivates advertising agencies to take up new initiatives in advertisement Advertisement in social media has facilitated Guerrilla marketing. Guerrilla artists are employed to promote products for advertising campaign. Guerrilla artists are used for social responsibility campaign like for cleanliness, medical insurance and aids awareness etc. Guerrilla marketing is different from traditional marketing as it is creative in nature; the cost involved for this advertisement is economical. Guerrilla marketing adapts to latest technology and more suitable for reputed company products. This type of advertisements appears in unexpected locations.

Ekrem Cetin Bigat in his article " Guerrilla advertisement and Marketing" stated that he examined the relationship between Traditional way of marketing with Guerrilla Marketing. He has mentioned that Guerrilla Marketing is cost effective and creative. They are concerned with increasing sales and profit. Globalization has brought transformation which has increased completion to market the product. Guerrilla Marketing is a nontraditional method used to promote their products.

\subsection{Conceptual Frame Work Of Guerrilla Marketing}

Katharina Klug and Stefan Hoffmann in their article "Guerrilla Marketing: The Nature of the Concept and Propositions for Further Research" ( 2011) highlights how different guerrilla instruments try to suggest these effects. There is rare empirical evidence about the efficacy of guerrilla marketing; the paper outlines a conceptual framework and several propositions for further research from consumer behavior perspective and managerial perspective. 


\subsection{Techniques In Advertisement}

Paul Suggest in his article "Major media tactics used in modern advertising to reach consumers"(2018) has pinpointed that there are many choice for advertisers. Online advertisements in internet, face book reaches mass customers through online. He has mentioned that the driving force behind guerrilla marketing is creative ideas that require less cost. This campaign will spread through word of mouth and social media

\subsection{Rebooting Customer Loyalty}

Gregg Petersen in his article "Rebooting Customer Loyalty in Experience Economy" (2017) stated that India is in digital transformation and it changes the way businesses work together with consumers today. Smart phones allow customers to inform changes, success or failure is not defined by distributing a good product, it is achieved by through consumer 'experiences' on a product. When customers experience bad about a product it leads to negative impact on the brand, but innovative companies can leverage this as an occasion to develop. Availability can move consumers from satisfied to loyal and eventually, make them brand advocates through positive experiences.

\section{OBJECTIVES}

- To analyze the importance of Guerrilla marketing

- To study the impact of Guerrilla marketing on Customers loyalty

- To offer suggestions to promote customer loyalty for Bata products

\section{IMPORTANCE OF GUERRILLA MARKETING}

As people are very busy, effective marketing becomes essential. The firms must adopt innovative marketing strategy to attract people to buy their products. Guerrilla marketing is definitely a solution to this problem. Organization has to spend huge amount for advertising through Medias like print and television, flyers and bill boards. Development of technology motivates advertising agencies to take up new initiatives in advertisement. Advertisement in social media has facilitated Guerrilla marketing. Guerrilla artists are employed to promote products for advertising campaign. Guerrilla artists are used for social responsibility campaign like for cleanliness, medical insurance and aids awareness etc. Guerrilla marketing is different from traditional marketing as it is creative in nature; the cost involved for this advertisement is economical. Guerrilla marketing adapts to latest technology and more suitable for reputed company products. This type of advertisements appears in unexpected locations. As per the RBI report it is understood that sales and Profit are in increasing trend. India is considered the biggest market in terms of sales by Bata Shoe Company. Bata India is focusing on digital marketing now. Due to cost reduction the company was in a position to earn more. For the year 2018 Bata is expecting a profit of 223.5 crores. Bata will be paying dividend Rs 4 per share. It will be possible by sustaining consumer loyalty

6'Table 1"
INVESTING RATIO
\begin{tabular}{|c|c|c|c|c|c|}
\hline Financial Ratios & 2011 & 2012 & 2013 & 2014 & 2015 \\
\hline Financial Leverage & 2.33 & 2.00 & 1.02 & 1.02 & 1.01 \\
\hline Earnings per share & 13.50 & 9.89 & 16.30 & 17.72 & 19.03 \\
\hline Price earnings ratio & 8.27 & 10.00 & 17.13 & 19.70 & 17.10 \\
\hline
\end{tabular}

Source: rbi.org.in - RBI Bulletin -2015

It is observed from the above table that cost of finance is decreasing. Financial leverage measures the cost of debt. Net income changes when compared to changes in EBIT. The ratio is in decreasing trend which signifies the cost of finance is decreasing.

Earnings per share reveals the income earned on each share which is also in increasing trend except in the year 2012. It indicates the earnings are in increasing trend.

Price earnings ratio shows the amount investor can expect to invest in a company. The high Price earnings ratio indicates that investors are expecting higher earnings in future compared to firms with lower Price earnings ratio. In Bata Company the ratio is in increasing trend that shows investors get good return.

The above statements clearly show the company is in growing stage. All this was possible by adopting guerilla marketing which is cost effective and the loyalty of customers continues to sustain for many years.

\section{RESEARCH METHODOLOGY}

This is a descriptive analysis. We have collected the data from different websites and by doing survey from customers in Chennai. Based on the research questions and study objectives, the following hypothesis framed:

- H1 There is a significant relationship between Guerrilla marketing and impact on Customers loyalty

\subsection{Customer loyalty}

Under globalised economy gaining customers found difficult, and sustaining them around is still harder. Gone are the days when offering good customer service considered essential, but that's not enough anymore. Customer loyalty is defined as, "A buyer's preference for doing business with a particular business establishment." It is the relationship between a satisfied patron and the business establishment. Social media is also a platform to attract new customers and to push new products. It is also used to retain existing loyal customers. Strategy to build relationship, maintaining their loyalty is possible when customers follow the company in social media. Social media is used as a tool to understand what their customers want, accordingly align their posts and products as per their customer's preferences.

\section{DATA ANALYSIS\& RESULTS}

Primary data collected from customers of Bata products in Chennai. 300 respondents were chosen through convenient sampling. Multiple regression analysis tools used that helps to predict the effect of independent variables on dependent variable. Multiple regression analysis determines the fit of 
the model and the relative contribution of each of the predictors to the total variance. The sustainability of loyalty of customers of Bata products analyzed. Guerilla marketing is executed for innovative and fashionable design, continuous update of their products, increasing brand awareness and reach mass customers to help their loyal customers. Each independent variable explains the variance. The impact of Guerrilla marketing on customer loyalty analyzed.

\subsection{Multivariate Analysis -Multiple Regression Analysis}

Regression is the determination of statistical relationship between two or more variables. When there are more than two independent variables the analysis concerning relationship is known as multiple correlations and the equation describing such relationship is called as the multiple regression equation. In this analysis, the dependent variable is the Customer Loyalty and the Independent variables are Guerilla Marketing Aspects i.e., Brand Awareness, Innovativeness, Continuous Update and Widest Coverage. Multiple Regression was conducted to determine the best linear combination of Brand Awareness, Innovativeness, Continuous Update and Widest Coverage for predicting Customer Loyalty.

"Table 2"

\section{REGRESSION COEFFICIENTS}

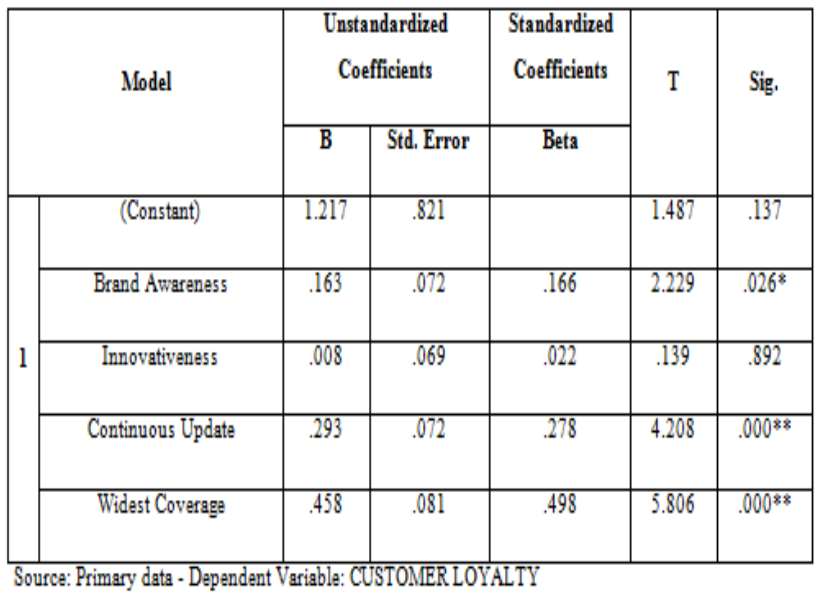

( $5 \%$ Level of Siginificance and ${ }^{* 8} 1 \%$ level of Sigificicance)

The combination of three out of four independent variables significantly predicts the dependent variable i.e., Customer Loyalty, F $(4,145)=121.443$,p values are lesser than .001 and 0.05 (Sig. Value 2-tailed). Out of four aspects of Guerilla Marketing, Widest Coverage (0.498) is the strongest influencing factor that predicting dependent variable Customer Loyalty. The higher the beta value the greater the impact of the predictor variable on the criterion (Dependent) variable. The beta weights suggest that the Widest Coverage only contribute most $(0.498$ or $50 \%)$ to predict Customer Loyalty. This means that this variable makes the strong unique contribution to explaining the dependent variable, when the variance explained by all other variables in the model is controlled for.

The Widest Coverage may have a standardized regression coefficient of 0.498. It means for every 1 Standard Deviation of increase in the Widest Coverage, scores on Customer Loyalty increase by 0.498 Standard Deviations, controlling for the scores of other variables in the equation. From the unstandardized coefficient, it is found that the one unit increase in the Widest Coverage would increase the Customer Loyalty by 0.458 units.

Continuous Update (0.278) and Brand Awareness (0.166) also predict the Customer Loyalty significantly but lesser than Widest Coverage. Innovativeness (0.022) does not predict Customer Loyalty significantly. Adjusted R2 provides the proportion of variation in the dependent variable that is explained by the independent variables in the model. The adjusted $\mathrm{R}$ squared value is 0.764 . This indicates that $76 \%$ of the variance in the Customer Loyalty can be predicted from the independent variables. Remaining $24 \%$ is unexplained. According to Cohen (1988), this is large effect.

Note: Cohen's Note (1988) guidance was adopted, where in a correlation coefficient of between 0.10 and 0.29 was taken as mall relation, between 0.30 and 0.49 as medium, and between 0.50 and 1.00 as large.

Figure 1

Research Model - Guerilla Marketing And Customer Loyalty

\section{GUERILLA MARKETING ASPECTS - CUSTOMER LOYALTY - RESEARCH MODEL}

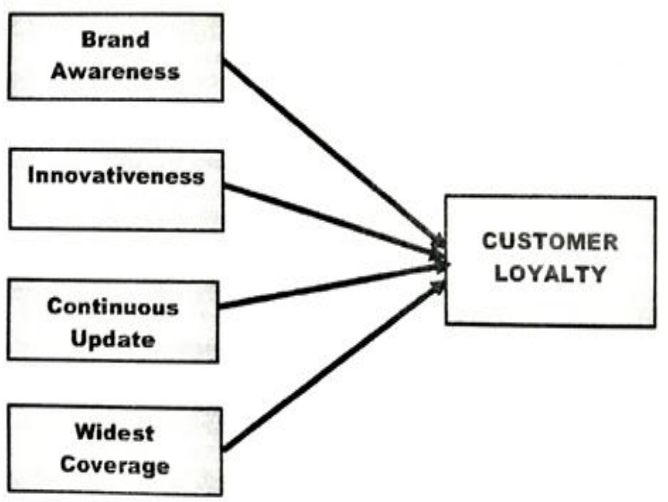

\section{FINDINGS}

- Widest Coverage only contributes most ( 0.498 or $50 \%)$ to predict Customer Loyalty.

- Customers have aversion on traditional advertising that makes direct attempt to buy something. Guerrilla marketing sell to customers without them knowing it is sold to them.

- Guerrilla marketers are confident that there is a reduction of up to $90 \%$ in their advertisement cost by going Guerrilla.

- Loyal customers truly believe in their company, and they are not shy in sharing their experience with anyone who will listen. The word of mouth will benefit the business.

- EPS of Bata company is in increasing trend for the past 5 years

- Cost of capital of Bata company is decreasing due to application of Guerrilla marketing

- Guerrilla marketing offers creative liberties, for showcasing Bata products in a unique way. 


\section{SUGGESTIONS}

- In Guerrilla marketing message must be given in such a way that makes the customers come back to them for more details instead of giving all details.

- Under Guerrilla marketing audiences must be the existing customers as they will quickly recognize and share the experience with their friends.

- Guerrilla marketing can't be repeated often as they lose their value. Hence it has to be structured to follow up more promotional acts to sustain loyal customers.

- With available resources, the reach and budget prepared for guerrilla marketing strategies must prove to be the right fit.

- Guerrilla marketing can sponsor a local event, like a function at a local school; they can be associated with loyal customers that's within their target demographic.

\section{CONCLUSION}

Bata shoes can be obtained at affordable prices. They have earned the reputation from customers due to the supply of good quality shoes; people expect the same durability from Bata. Bata focus on designed products with focus on durability and price. From the study on Bata Shoe Company we have analyzed that they are growing and their weakness is lack of progress with the speedy changing market needs, insufficient promotional activities, and diminish in quality. Bata company distribution channel system is very effective. Bata Shoe Company is one of the upcoming competitors in the shoe industry. Bata is taking corrective actions in all ways by adapting guerilla marketing to be cost effective and to sustain the existing customer's loyalty. Making customers loyal to their business helps with word of mouth marketing, customer retention, rate of patronage, feedback, and competitive advantages. To make the customers loyal they have to be updated about the new fashionable products, offers given at cost effectiveness by the company.

\section{REFERENCE}

1. Business Line

2. Businessworld.in

3. Guerilla marketing, done right, can be incredibly cost-effective and powerful By Trendjackers Team -2917

4. Guerrilla Marketing Research: Marketing Research Techniques That Can Help Any Business Make More Money 01 Edition by Robert J Kaden

5. Guerrilla Marketing Tactics That Are Still Relevant in 2017 by Michael Manning

6. Hitesh Bhasin -marketing mix of Bata

7. Journal of marketing Research

8. Marketing Management by Philip Kotler and Keven Lane Keller

9. Management and economy magazine

10. Services Marketing by C. Bhattacharya

11. The Best Guerrilla Marketing Tactics for Small Businesses by Jeanna Barrett

12. The economic Times

13. The Guerrilla Marketing Revolution by Jay Conrad Levinson Paul R. J. Hanley- Publisher: Little, Brown Book Group

14. Exchange 4 media .com

15. www.thebalancecarreers.com 